\title{
Analysis of Factors Affecting Teacher Competence Physics Science SMP in the District of West Seram Maluku Province
}

\author{
Dr. Izaak Hendrik Wenno, S.Pd., M.Pd* \\ Study Program of Physics, Faculty of Teaching and Education University of Pattimura Ambon
}

\begin{abstract}
Teacher competence is one aspects that affecting the educational quality in many country over the world. Teacher competence was affected by some factors. These factors including teacher creativity, teacher interest, teacher attitude, teacher motivation to work, and motivation to achieve, principal leadership, school culture, compensation, job satisfaction, and school facilities. Science physics teacher competence also affected by these factors. In junior high school in West Seram Regency, the competence of science physics teacher was not well documented. This research aim was to determine the most important factors that affect the science physics teacher competence in junior high school in West Seram Regency. Research variables that were measured consist of science physics teacher creativity $\left(X_{1}\right)$, science physics teacher motivation to work $\left(X_{2}\right)$, science physics teacher interest $\left(X_{3}\right)$, science physics teacher attitude $\left(X_{4}\right)$, science physics motivation to achieve $\left(X_{5}\right)$, compensation $\left(X_{6}\right)$, job satisfaction $\left(X_{7}\right)$ school culture $\left(X_{8}\right)$, Principal leadership $\left(X_{9}\right)$, and facilities in the school $\left(X_{10}\right)$. The obtained data then analyzed by using the principle component analysis to reveal the most variable that affecting science physics teacher competence in the junior high school in South West Seram Regency. that from 10 factors that affect the competence of teachers, there are seven factors that most affect the competence of science physics teachers at junior high school in West Seram Maluku Regency. These factors identified as an internal factors (interests, attitudes, and creativity of teachers ), and external factors, namely the principal's leadership, compensation, school culture, and school facilities.
\end{abstract}

Keywords: science physics, teacher competence

\section{Introduction}

Education is a vehicle to improve and develop the quality of human resources of a nation. Through education, competitiveness, self-esteem, integrity, quality, character, and welfare of a nation can be measured. The quality of education in Indonesia until this center continue to be pursued improvement. Efforts to improve the quality of education in Indonesia is done through various methods and approaches through policy, legislation, budget allocation, to the implementation of the various educational units both the primary level, secondary to university tingggi (Achwarin 2009; Triyanto, 2012; OCED, 2015).

Teachers are the main components that determine the success of the implementation process of education in schools. The role of the teacher in the school is very important to improve the quality of learners (UNESCO, 2015). As stated in the Law of the Republic of Indonesia Number 20 of 2003 on National Education System that teachers are the professionals with the task of teaching and learning process that starts from the preparation, implementation, and evaluation of teaching and learning.

In learning activities the teacher acts as a facilitator, leader, and manager (Mustafa, 2013). Teachers also have a double duty that as a teacher and educator. As a teacher of teachers assigned to teach a lesson material to students. As teacher educators will provide assistance and guidance to the students. The purpose of supervision and pembinan is to form students' character appropriate norms of decency, civilized, and had to be creative and active and independent in the future (Akhyak et al., 2013).
In this era of growing current with advances in information technology and communication, we need qualified teachers and have high competence. The era of globalization, teachers are required to further improve their competence, because the quality of education is largely determined by the ability or professional competence of a teacher.

Law of the Republic of Indonesia No. 14 Year 2005 on Teachers and Lecturers stipulates that "a competent teacher is a teacher who has a number of science and master the skills that can be applied in teaching and learning activities that teachers become more professional". Competent teachers is also interpreted as a teacher who has a number of basic abilities or skills. Ability and skill are interrelated with the duty and responsibility of the teacher as an educator. The purpose of the effort for teachers as professionals is that the system of national education can be implemented and realized, so that the formation of the next generation of the nation's future that is faithful and devoted to God Almighty, noble, healthy, knowledgeable, skilled, creative, independent, and become citizens democratic and responsible can be achieved. Teacher competence as stated in the law, then translated into four main themes namely paedagogik competence, professional competence, personal competence and social competence (Celik, 2011; Sinaga et al., 2014).

Pedagogical competence is the ability of teachers with regard to the management of learners. By having this competence, teachers are expected to have insight and understanding of the foundations of education. Teachers are also expected to have an understanding of learners, to develop curriculum and learning tools, designing and implementing the learning process, to evaluate the results of learning. Teachers are also required to be able to explore the 


\section{International Journal of Science and Research (IJSR) ISSN (Online): 2319-7064 \\ Index Copernicus Value (2013): 6.14 | Impact Factor (2015): 6.391}

potential possessed by the student to be developed (Liakopoulon 2011; Syahruddin et al., 2013).

Naumescu (2008) and Ahmad Yani et al. (2015) states that the professional competence requires that teachers have the ability to stimulate critical thinking skills in students. Teachers hraus master the subject matter, and use appropriate methods to teach it. Teachers should be able to connect between concepts with everyday life. Teachers should give real examples and capable of forming understanding in students.

Competent and professional teachers are teachers who are skilled in performing their duties. Professional competence of teachers is also defined as the ability of teachers to teach subjects or disciplines is broad and deep, and help students achieve standards mastery learning outcomes (Oliver, 1990; Simeonidis, 2015). Mustafa (2013) states that professional teachers are teachers who have the ability and special skills in the field of teacher training, and able to carry out its duties and functions as a teacher to the fullest. In an effort to improve the quality of education and graduates, the competence of teachers needs to be improved.

Personal competence is the ability of teachers to serve as models to the students. Teacher who has a good personality, adult, mature, and wise would be an example or role model for students and in the community. Teachers will be able to evaluate their own personal appearance, and also develop the potential in him. Social competence is the ability of educators as part of the community to communicate orally and in writing, using information and communication technology functionally interact effectively with students, fellow teachers, staff, parents / guardians of students, and interact politely with the surrounding community.

Competence of teachers, influenced by many factors. Tambunan (2014) mentions the factors that affect the competence of teachers, school leadership, school culture, school facilities, motivation, achievement motivation, compensation, job satisfaction, the interest of teachers, teacher attitudes, and creativity of teachers.

Learning physics is an explorative learning. Learning physics is not monotonous only in the classroom, but rather lead to implementation into a tangible form. To improve students' mastery and understanding of physics, a science teacher of physics, must have competence over the competency of teachers that have been defined. A teacher should be able to master the science of physics knowledge and skills related to physics, and able to implement the theories taught through practice and demonstrations. Physical science teachers should have the skills to use the equipment in the laboratory of physics, as well as having the ability to explain the function and use of any equipment used (Render, 2011; Purwandari, 2015).

Observations indicate that the science teachers in middle school Physics First District of West Seram not have competence as required. Generally, teachers have to prepare lessons maksimalpembelajaran done in class, still monotonous, and limited to the use of classical lecture method. Teachers are more focused on the achievement of the curriculum, from the student's mastery. Learning begins with a lecture followed by the assignment. Students are assigned to do the exercise on a few questions. Sometimes, students do not understand what the purpose of the questions and assignments given. Students also do not know the exact formula to work on the problems given task. The task given also never discussed together. With limited school facilities and the unavailability of qualified physics laboratory, then the learning is done only cause confusion on the students. Students do not understand the topic being taught. Learning students merely memorize. When an exam, student learning outcomes do not show the maximum gains.

The facts is alleged influence of teacher competence especially physical science teachers in secondary schools in the District of West Seram. Based on the background described, the goal of this study was to determine the factors that most affect the competence of physics junior high science teacher in West Seram regency.

\section{Method}

\subsection{Place and Time Research}

The study was conducted in 24 secondary schools in West Seram regency (SBB) in October - December 2015.

\subsection{Population and Sample}

The school population in this study were all junior secondary schools in West Seram regency as many as 24 schools. 5\% confidence that the school acquired sebanayak 10.90 (rounded to 11). The number of teachers in each school physics is 3-5 people. Therefore, all teachers at 24 schools of physics are taken as samples, so that the total sample is about 90 physics teacher.

\subsection{Research Instruments}

The research instrument used was a questionnaire prepared following the Likert scale. Each statement consists of five answer choices. The statement consists of a choice answers with values strongly agree (5), agree (4), disagree (3), disagree (2), and 1 (strongly disagree).

\subsection{Variables measured}

The research variables consist of independent variables that school leadership (X1), motivation (X2), interest in physics teacher (X3), the attitude of teachers of physics (X4), achievement motivation (X5), the compensation awarded (X6), job satisfaction ( X7) school culture (X8), physics teacher creativity (X9), (X10) facilities / means of learning, and the dependent variable (dependent), namely physical science teacher competence (Y).

\subsection{Research procedure}

Before being used for research, instrument each variable tested to determine its validity and reliability. The trial was conducted on 20 teachers in five schools. After the validity and reliability, grains invalid statement issued from the instrument, thereby leaving only the grains statements are 


\section{International Journal of Science and Research (IJSR) \\ ISSN (Online): 2319-7064 \\ Index Copernicus Value (2013): 6.14 | Impact Factor (2015): 6.391}

valid and reliable. Having obtained a valid and reliable instrument, the instrument is then used for real research.

Validity and reliability of the instrument was conducted to test whether the gauge (instrument) that is used to qualify as a good measuring tool, and qualifies as a measuring tool to measure what is being measured. Validity test is done based on the value of the Pearson Product Moment Correlation. The acceptance criteria is if the correlation coefficient Product_Moment> 0.25 then the item is valid instrument
(Marguiriete et al., 2006). Test reliability using Cronbach Alpha coefficients with the test criteria is if the value of Cronbach alpha $>0.90$, the reliability is very high (Hilton \& Brownlow, 2004; Lounsbury et al., 2006).

Objective validity and the reliability is to get the instrument that is truly valid and reliable. In this study, the validity and reliability made to the instruments variables X1 to X10 and $\mathrm{Y}$ variables are competence of teachers (Table 1).

Table 1: Results of the validity and reliability of research instrument

\begin{tabular}{|c|c|c|c|c|c|c|}
\hline Nama variabel & $\begin{array}{c}\text { Total instrument early } \\
\text { (before validity test) }\end{array}$ & $\begin{array}{l}\text { Total final instrument } \\
\text { (After the test validity) }\end{array}$ & $\begin{array}{c}\text { Value Range } \\
\text { validity }\end{array}$ & category & $\begin{array}{c}\text { Reliability } \\
\text { value }\end{array}$ & category \\
\hline $\mathrm{X} 1$ (techer crativity) & 30 & 29 & $0.307-0.872$ & Valid & $0.962-0.965$ & Reliable \\
\hline $\mathrm{X} 2$ (motivation) & 48 & 22 & $0.296-0.788$ & Valid & $0.871-0.882$ & Reliable \\
\hline X3 (teacher interest) & 40 & 18 & $0, .271-0.723$ & valid & $0.834-0.854$ & Reliable \\
\hline X4 (Teacher attitude) & 45 & 19 & $0.306-0.756$ & Valid & $0.871-0.888$ & reliable \\
\hline X5 (achievent motivation) & 40 & 19 & 0.316-0.613 & Valid & $0.869-0.882$ & Reliable \\
\hline X6 (compensation) & 35 & 17 & $0.268-0.752$ & valid & $0.826-0.849$ & Reliable \\
\hline X7 (job satisfaction) & 30 & 18 & $0.295-0.731$ & Valid & $0.863-0.874$ & Reliable \\
\hline X8 (school culture) & 30 & 25 & $0.265-0.851$ & Valid & $0.957-0.962$ & reliable \\
\hline X9 (school leadership) & 45 & 18 & $0.291-0.671$ & Valid & $0.868-0.882$ & Reliable \\
\hline X10 (fasilities) & 30 & 29 & $0.322-0.929$ & Valid & $0.970-0.973$ & Reliable \\
\hline Y (teacher competency) & 30 & 29 & $0.502-0.908$ & Valid & $0.970-0.971$ & reliable \\
\hline
\end{tabular}

Having obtained a valid and reliable instrument, then the instruments are used for real research to the 90 respondents in 24 schools. The data obtained and analyzed using principal component analysis to find out of the ten variables that affect the competence of teachers, which variables most affect the competence of physical science teachers in secondary schools in the District of West Seram.

\subsection{Data analysis technique}

Analysis of the validity, reliability and principal component analysis was performed using SPSS version 18.00.

\section{Result}

Prior to principal component analysis, testing should be performed analysis requirements. Test requirements for the analysis of main components of feasibility and the adequacy of the sample. Feasibility and the adequacy of the sample consisted of two by looking at the value of Keiser-MeyersOklin (KMO) Measure of Sampling Adequacy and Barlett Test value of Sphericity. If the value of KMO $>0.5$ and a significance value Bartlest Test of Sphericity $<0005$ then the sample can be said to be feasible and meets the adequacy size to be analyzed by principal component analysis (Table $1)$.

\begin{tabular}{|c|c|c|}
\hline \multicolumn{3}{|c|}{ KMO and Bartlett's Test } \\
\hline Kaiser-Meyer-Olkin Measure of Sampling Adequacy. & .618 \\
\hline $\begin{array}{c}\text { Bartlett's Test of } \\
\text { Sphericity }\end{array}$ & Approx. Chi-Square & 178.870 \\
\cline { 2 - 3 } & Df & 45 \\
\cline { 2 - 3 } & Sig. & .000 \\
\hline
\end{tabular}

KMO calculation results (Table 1) of 0.618 indicates the adequacy of the sample including the medium category. Value Barlett Test of Sphericity amounted to 178870 at the 0.000 significance, which means that the dataset variables affecting teacher competence used in this study deserves to be analyzed by principal component analysis. The next stage of the analysis of the main components is the reduction of the variable. Since the objective of the principal components analysis is to reduce the number of variables that many become new variables with smaller dimensions, but was able to explain or provide information about the subject as a whole, it must be done through a variable reduction test Measure of sampling adequacy (MSA). Value MSA showed a correlation between the variables. If the value of MSA> 0.5 then the variables can be used for principal component analysis (Table 2).

Table 2: The value of each variable for the MSA Principal Component Analysis

\begin{tabular}{|l|c|c|}
\hline Variabel & Nilai MSA & explanation \\
\hline $\mathrm{X}_{1}$ (teacher's creativity) & 0.532 & Used \\
\hline $\mathrm{X}_{2}$ (teacher motivation) & 0.369 & Dropped \\
\hline $\mathrm{X}_{3}$ (interests of teachers) & 0.504 & Used \\
\hline $\mathrm{X}_{4}$ (attitudes of teachers) & 0.711 & Used \\
\hline $\mathrm{X}_{5}$ (achievement motivation) & 0.421 & Dropped \\
\hline $\mathrm{X}_{6}$ (compensation) & 0.631 & Used \\
\hline $\mathrm{X}_{7}$ (job satisfaction) & 0.391 & Dropped \\
\hline $\mathrm{X}_{8}$ (school culture) & 0.642 & Used \\
\hline $\mathrm{X}_{9}$ (school leadership) & 0.639 & Used \\
\hline $\mathrm{X}_{10}$ (school facilities) & 0.730 & Used \\
\hline
\end{tabular}

Values of correlation between variables showed that there is a variable that can not continue to be analyzed in a principal components analysis because it has the MSA $<0.5$. Based on data in Table 2, the variables that can be used for principal component analysis (grades MSA more than 0.5) are variable X1 (creativity teacher), X3 (interests teacher), X4 (attitudes of teachers), X6 (compensation), X8 (culture school), X9 (school leadership) and X10 (school facilities), while the variable $\mathrm{X} 2$ (motivation of teachers), X5 (achievement motivation), and X7 (job satisfaction) can not be used for principal component analysis because it has no 


\section{International Journal of Science and Research (IJSR) \\ ISSN (Online): 2319-7064 \\ Index Copernicus Value (2013): 6.14 | Impact Factor (2015): 6.391}

correlation between the variable (MSA value <0.5). Subsequent analysis is to determine how the main component is formed, which is based on the value of root traits (Eigen value / Eigen value) more than one (Morison, 1976).

Table 3: Eigenvalues for determining the amount of the main components

\begin{tabular}{|c|c|c|c|}
\hline \multirow{2}{*}{ Component } & \multicolumn{3}{|c|}{ Initial Eigenvalues } \\
\cline { 2 - 4 } & Total & \% of Variance & Cumulative \% \\
\hline $\mathbf{1}$ & $\mathbf{2 . 6 0 9}$ & $\mathbf{3 7 . 2 7 2}$ & $\mathbf{3 7 . 2 7 2}$ \\
\hline $\mathbf{2}$ & $\mathbf{1 . 1 1 3}$ & $\mathbf{1 5 . 9 0 2}$ & $\mathbf{5 3 . 1 7 4}$ \\
\hline $\mathbf{3}$ & $\mathbf{1 . 0 5 0}$ & $\mathbf{1 5 . 0 0 3}$ & $\mathbf{6 8 . 1 7 7}$ \\
\hline 4 & .959 & 13.706 & 81.883 \\
\hline 5 & .661 & 9.442 & 91.325 \\
\hline 6 & .435 & 6.210 & 97.534 \\
\hline 7 & .173 & 2.466 & 100.000 \\
\hline
\end{tabular}

Table 3 describes the Eigen value of each component as well as the percentage of variance (\% of variance) and percent cumulative. From the data in Table 3 above, there are three major components that have more than one value Eigen. The first main component with Eigen value 2.609 (a variant of $37.27 \%$ ), the second major component has Eigen value of 1.113 (variance of $15.90 \%$ ), the third major component has Eigen value of 1.050 (a variant of 15:00\%). Cumulative three main components will be able to explain the diversity of data at $68.17 \%$. To determine what variables are included in the three main components newly formed, or of variablevariables are set to go into components which, and variables that can actually be used as an indicator variable competence of science teachers of physics, then the rotation factor (transformation) with varimax factor rotation method (Table 4). The result of the rotation of factors place a variable included on or in which the main components. It is influenced by the value of the so-called value of loading (loading factor). Loading value indicates the magnitude of the relationship or the influence of a variable to a component that causes these variables go into specific components. Loading the greatest value of a variable in the main components allow a variable that goes into the main component.

Table 4: Values Loading (Loading factor) variables of the main components

\begin{tabular}{|c|c|c|c|}
\hline \multicolumn{4}{|c|}{ Rotated Component Matrix } \\
\hline & \multicolumn{3}{|c|}{ Component $^{\mathbf{a}}$} \\
\hline & 1 & 2 & 3 \\
\hline $\mathrm{X} 1$ & -.076 & $\mathbf{. 6 3 5}$ & -.045 \\
\hline $\mathrm{X} 3$ & .103 & .010 & $\mathbf{. 9 2 0}$ \\
\hline $\mathrm{X} 4$ & .186 & $\mathbf{. 6 9 3}$ & .034 \\
\hline $\mathrm{X} 6$ & $\mathbf{. 6 9 6}$ & .495 & .296 \\
\hline $\mathrm{X} 8$ & $\mathbf{. 7 7 3}$ & .380 & .206 \\
\hline $\mathrm{X} 9$ & $\mathbf{. 7 9 8}$ & -.069 & -.385 \\
\hline $\mathrm{X} 10$ & $\mathbf{. 6 5 8}$ & -.179 & .364 \\
\hline
\end{tabular}

Extraction Method: Principal Component Analysis. Rotation Method: Varimax with Kaiser Normalization

a. Rotation converged in 5 iterations
After rotation factor by varimax method, it can be seen the relationship between the variables of origin with new components (principal component) is formed, as well as the grouping variable into the new component through the PCA called value loading. The value of the variable loading showed a correlation between the origin of the newly formed components. These results are described for example in variable $\mathrm{X} 1$ has a correlation with the factor (major components) first at -0076 , with the two main components of 0635 , and with the 3 main components amounted to 0045. Thus, the variable X1 into the second main component because it has the greatest loading on the second main component. This explanation is used to classify X3, X4, X6, $\mathrm{X} 8, \mathrm{X} 9$, and X10. The amount of loading the selected value is the largest. The variables that have the greatest loading value (in bold) is the variable chosen, the indicator variables that can be used as variables that most affect the competence of junior high science teacher physics in West Seram regency. The use of these variables as a variable indicator means that, if a person (researcher or practitioner) wanted to choose teachers who are competent, should be based on these variables are: interest of teachers, teacher attitudes, creativity of teachers, kompenssi, school culture, school leadership, and school facilities. Based on the data in Table 4 also can be known variables included in the main component first, second or third in detail shown in Table 5.

Table 5: Grouping variables into a newly formed components

\begin{tabular}{|c|c|c|c|}
\hline $\begin{array}{c}\text { Main } \\
\text { Component }\end{array}$ & variabel & $\begin{array}{c}\text { Loading } \\
\text { value }\end{array}$ & $\begin{array}{c}\text { Varian } \\
\text { described }\end{array}$ \\
\hline \multirow[t]{4}{*}{1} & $\mathrm{X}_{6}$ (compensation) & 0.696 & \multirow[b]{4}{*}{37.27} \\
\hline & $\mathrm{X}_{8}$ (school culture) & 0.773 & \\
\hline & $\mathrm{X}_{9}$ (school leadership) & 0.798 & \\
\hline & $\mathrm{X}_{10}$ (school facilities) & 0.658 & \\
\hline \multirow[t]{2}{*}{2} & $\mathrm{X}_{1}$ (teacher's creativity) & 0.635 & \multirow[t]{2}{*}{15.90} \\
\hline & $\mathrm{X}_{4}$ (attitudes of teachers) & 0.693 & \\
\hline 3 & $\mathrm{X}_{3}$ (interests of teachers) & 0.920 & 15.00 \\
\hline
\end{tabular}

Table 5 also can be used to define the components that form seen from their constituent variables. The first major component consists of variable compensation, workplace culture, leadership principals, and school facilities. The main components of the 2 nd consisting of variable creativity of teachers and the attitudes of teachers, while the third main component consists of a variable interest teachers. The main component of the first, second, and third can be defined based on the variable constituent. The first main component can be called personal factors beyond the teacher, while the second and third main component may be cited as the factor of private teachers. This shows that the competence of physical science teachers in secondary schools spooky western districts affected by two factors, namely factor from itself (intrinsic), and factors outside themselves (environmental factors work).

\section{Discussion}

\subsection{Internal factors which mepengaruhi physical science teacher competence}

Internal factors affecting teachers from within the competence of science teachers in the junior high school

\section{Volume 5 Issue 6, June 2016 www.ijsr.net}




\section{International Journal of Science and Research (IJSR) \\ ISSN (Online): 2319-7064}

Index Copernicus Value (2013): 6.14 | Impact Factor (2015): 6.391

physics kapubaten spooky western part of that creativity, attitudes, and interests of teachers. It is known that the attitudes and interests and creativity are the three elements are interrelated. If a teacher has a high interest in the profession keguruannya, it will form a positive attitude in the teacher on duty. Their positive attitude to encourage teachers to work more optimally.

Nadeem et al. (2011) states that attitude is a tendency to respond like or absence of an object. Moreover, the attitude also contains motivation, which means that the attitude has impetus for individuals to behave towards the object. Teacher attitudes toward work implies a form of evaluation or as a reaction to the feeling of a teacher to the work performed by him, in this case as educators and teachers in the school.

Interests of teachers and teachers' creativity also affects the competence of teachers. It is common knowledge that the interest is a factor that greatly affects attitudes and behavior. If someone has a keen interest, then that person will show a positive attitude and support its activities. If a teacher has a high interest in the science of physics, the teacher will have a high motivation and a positive attitude as well as increase kreatiftas teachers. The progress of the times faster then the teachers are required to adapt the overall good of the implementation of education and specific skills that surrounded him. With existing interest, will encourage teachers to look for the latest information related to the subjects they teach. Teachers will adapt the knowledge gained by the development and the demands of time. Teachers will find the latest information to improve both their creativity in teaching and learning as well as in the preparation of learning tools and instruments needed for learning.

\subsection{External factors that affect physical science teacher competence}

One of the external factors that affect physical science teacher competence is compensated. It is known that the compensation is the gift of rewards or awards to the performance of teachers (Kusumaningtyas \& Setyawati, 2015). Compensation affect the competence of teachers, because with the compensation of the material can be used to develop competencies such as teacher training or scientific seminars, and other supporting materials, or purchase course materials to enrich their knowledge. Government recognition of the performance of teachers in Indonesia are carried out in the form of allowance teacher certification. Zaharah (2014) states that there is significant influence between administration of the certification of the quality of teachers. Compensation in the form of appropriate materials, will also improve the welfare of teachers. Teachers who prosper economically or finance will concentrate on work. Compensation may also be in the form of praise or appreciation for teacher performance. It is an appreciation given to teachers who succeeded in teaching duties or managed to obtain an accomplishment. With the praise or recognition, will increase the confidence of teachers so that more and more compelled to work, which in turn will increase the competence (Sukiman \& Mintarti, 2016).
School leadership, school culture and school facilities are other external factors that affect the competence of physical science teachers in secondary schools spooky western districts. The third factor is essentially interrelated, and affect the competence of teachers.

School leadership affect physical science teacher competence, because the principal is a leader in a school organization. School leadership is a factor that plays an important role in shaping the school atmosphere was good and support all activities of learning and education in schools (Rahardjo, 2014). Principal leadership in question is in accordance with the principles of school-based management (Fitriati et al., 2014; Hutabarat, 2015a).

School-based management in question is a successful school leadership influence, direction, and move all the components in the school to perform a task with a goal-oriented school. Besides oriented tasks, school leadership should also create human relationships and bring teachers to the appropriate leadership style to the conditions (Hutabarat, 2015a).

As stated by Hutabarat (2015a) with the appropriate school leadership based on the principles of school-based management, it is expected that teachers can improve their performance, so as to boost the quality of students in the school in the form of academic and non academic achievement. This can be achieved well when there is achievement of the factors that encourage teachers to perform their jobs effectively.

Corresponding principal leadership, will create a school culture that supports the successful implementation of education in schools. School culture includes a healthy school climate, conducive working situation and humanist, as well as the existing infrastructure in these schools (Mutmainah et al., 2013). Quality schools have a healthy work culture and situation conducive working and supported by adequate means-infrastructures that will support each teacher to work (Hutabarat, 2015b). To create situations that favor, then inseparable from the role and cooperation between the principal and all the elements that exist in the school, so the climate situation and healthy workplace conducive can be achieved and maintained to support all educational process taking place at the school ( Fitriyati et al., 2014; Hutabarat, 2015b).

By working facilities were adequate, it is expected that teachers can carry out the learning process better and be able to optimize capability on him, so that the ability of teachers penguasasaan learning material will be wider and deeper that allows guiding learners to meet the standards of competence specified in National Standard Education. Moelyasa (2005) states that the facility is working all the tools, equipment and other facilities that serve as main or auxiliary tool in the execution of the work, and social functioning in the framework of the interests of people who are related to the work organization. 


\section{International Journal of Science and Research (IJSR) \\ ISSN (Online): 2319-7064}

Index Copernicus Value (2013): 6.14 | Impact Factor (2015): 6.391

\section{Implications and Suggestions}

Physical science is a subject that is important, because it has been linked to the mastery of science and technology. Given the importance of physical science, we need competent physical science teacher. Physics teacher competence can be obtained through sustained effort and continuous. Neither the teachers nor the government should focus on improving the quality and competence of teachers. Teachers must push to improve their competence.

Teachers must continue to learn, to follow the scientific activities such as training, seminars, workshops, or workshops to further broaden their horizons, increase experience and implement it in their teaching activities undertaken by teachers. Physical science teachers in secondary schools in the district spooky western part should be open and adjust to global changes that occur. Teachers must actualize the application of science to students through real-world examples. Teachers need to develop tools appropriate subjects to student characteristics. Teachers have to find a lot of references to support his learning to be more qualified and produce graduates with science process skills are maximized. To officials from the relevant agencies, should strive to increase the quality of the supporting infrastructure of learning, teachers' welfare should be improved through the provision of benefits and incentives, the principal must have the leadership in accordance with the basic principles of school-based management, and create a school environment that is conducive and iklm support the creation of effective schools and supporting the success of teaching and learning in schools. Principals should perform its function as a manager, supervisor, administrator, and leader to the fullest.

\section{Conclusion}

Based on the findings, it was concluded that of the 10 factors that affect the competence of teachers, there are seven factors that most affect the competence of science teachers of physics at secondary school in the District of West Seram Maluku Province that factor identified as a factor of the (interests, attitudes, and creativity of teachers), as well as outside factors, namely the principal's leadership, compensation, workplace culture, and school facilities.

\section{References}

[1] Achwarin, N. A. (2009). The Study Of Teacher Competence Of Teachers At Schools In The Three Southern Provinces Of Thailand Retrieved from www.journal.au.edu/scholar/2009/.../nareeAwareAchw arin156.doc

[2] Ahmad Yani., Rianita, L., \& Utami, R. 2015. Teacher's professionalism and its affecting factors: a review on EFL teachers' perceptions in Indonesia. International Journal of Languange and Applied Linguistics World, 8(4): 1-14.

[3] Celik, S. (2011). Characteristics and Competencies for Teacher Educators: Addressing the Need for Improved Professional Standards in Turkey. Australian Journal of Teacher Education, 36(4). http://dx.doi.org/10.14221/ajte.2011v36n4.3
[4] Fitriyati, R., Romdana, R., \& Rosyidi, U. (2014). The Practice of the Achool Principal's Leadership in Sekolah Indonesia Kuala Lumpur (SIKL): The Study of Leadership Styles and Techniques with Cognitive Mapping Aproach. Procedia Social and Behavioral Sciences 115 (2014): 258-268.

[5] Hutabarat, W.(2015a). Impleentation of School Based Management in Indonesia (Affecting Work Motivation, Job-Satisfaction, and Teacher Job Performance). International Journal of Sciences Basic and Ampplied Research, 22 (2): 428-440.

[6] Hutabarat, W. (2015b). Investigation of Teacher Job Performance Model: Organization Culture, Work Motivation, and Job-Satisfaction. Asian Social Science, 11(18) 295-304.

[7] Kusumaningtyas, A., \& Setyawati, E. 2015. Teacher Performance of the State Vocational High School Teachers in Surabaya. International Journal of Evaluation and Research in Education. 4(2): 76-83.

[8] Liakopoulon, M. 2011. The Professional Competence of Teachers: Which qualities, attitudes, skills and knowledge contribute to a teacher's effectiveness?. International Journal of Humanities and Social Science Vol. 1 No. 21 [Special Issue - December 2011: 66-78

[9] Morison, D.F. (1976). Multivariate Statistics Methods, $2^{\text {nd }}$ Edition, New York: McGraw-Hill.

[10] Mustafa, M.N. 2013. Factors that Influence Quality Service of Teacher. International Journal of Bisiness and Social Research, 3 (1): 32-37.

[11] Mustafa, M.N. 2013. Professional Competency Differences among High School Teachers in Indonesia. International Education Studies; Vol. 6, No. 9:83-92

[12] Mutmainah., Troena, E.A., \& Noermijati. 2013. Organizational Culture, Leadership Style Influence on Organizational Commitment and Performance of Teachers. International Journal of Business and Behavioral Sciences. 3(10): 54-65

[13] Naumescu, A.K. 2008. SCIENCE TEACHER COMPETENCIES IN A KNOWLEDGED BASED SOCIETY. Acta Didactica Napocensia, 1(1): 26-31

[14] OECD/Asian Development Bank (2015), Education in Indonesia: Rising to the Challenge, OECD Publishing, Paris. http://dx.doi.org/10.1787/9789264230750-en

[15] Oliver, B. 1990. Defining Competence: The Case of Teaching. JOURNAL OF TEACHING IN PHYSICAL EDUCATION, 1990, 9, 184-188

[16] Rahardjo, S. 2014. The Effect of Competence, Leadership, and Wotk Environment towards Motivation, and Its Impact on the Performance of Teacher of Elementary School in Surakarta City Central Jaya Indonesia. Inter national Journal oof Advanced Research in Management and Social Sciences. 3(6): 59-74.

[17] Render, I. 2011. 10 Skills and Competencies for Science Majors. Collegiate Employment Research Institute Recruiting Trends Note 3-2011

[18] Simeonidis, V. 2015. The Status of Teachers and the Teaching Profession A study of education unions' perspectives. Education International.

[19] Sinaga, P., Suhandi, A., \& Liliasari. 2014. The Effectiveness of Learning to Represent Physics Concept Approach: Preparing Pre-Service Physics Teachers To Be Good Teachers. Impact: International 


\section{International Journal of Science and Research (IJSR) \\ ISSN (Online): 2319-7064}

Index Copernicus Value (2013): 6.14 | Impact Factor (2015): 6.391

Journal of Research in Applied, Natural and Social Sciences (IMPACT: IJRANSS) ISSN(E): 2321-8851; ISSN(P): 2347-4580 Vol. 2, Issue 4, Apr 2014, 127136.

[20] Sukiman., \& Mintarti, S. 2016. The Effect of Compensation to Commitment, Motivation, and Performance of Vocational Teachers in Samarinda, East Kalimantan Province Indonesia. International Journal of Business and Management Invention. 5(2): 01-10.

[21] Syahruddin, Andi Ernawati, Muh. Nasir Ede. (2013). Teachers' Pedagogical Competence in School-Based Management. Journal of Education and Learning. Vol.7 (4) pp. 213-218.

[22] Triyanto, 2012, Improving Teacher Profesionalism through Certification Program: An Indonesia Case Study. World Academy of Science, Engineering and Technology International Journal of Social, Behavioral, Educational, Economic, Business and Industrial Engineering Vol:6, No:7, 2012' 1868-1872.

[23] Undang-undang Republik Indonesia No. 14 tahun 2005, Tentang Guru dan Dosen, (Surabaya: Kesindo Utama, 2006), hlm. 5.

[24] UNESCO. 2015. TEACHERS AND EDUCATIONAL QUALITY: Monitoring Global Needs for 2015. UNESCO Institute for Statistics, Montreal, 2006.

[25] Zaharah. 2014. The Effect of Certification and Competency towards Teachers Quality in MAN 3 High School Tangerang Indonesia. American Journal of Educational Research, 2 (5): 267-271.

Volume 5 Issue 6, June 2016 www.ijsr.net 